\title{
Sugars Replacement as a Strategy to Control the Formation of $\alpha$-Dicarbonyl and Furanic Compounds during Cookie Processing
}

\author{
Fabrizio Cincotta ${ }^{1}\left(\mathbb{D}\right.$, Selina Brighina ${ }^{2}$, Concetta Condurso ${ }^{1}$, Elena Arena ${ }^{2, *}$, Antonella Verzera ${ }^{1}$ \\ and Biagio Fallico 2 \\ 1 Department of Veterinary Sciences, University of Messina, Polo Universitario dell'Annunziata, \\ 98168 Messina, Italy; fabrizio.cincotta@unime.it (F.C.); concetta.condurso@unime.it (C.C.); \\ antonella.verzera@unime.it (A.V.) \\ 2 Dipartimento di Agricoltura, Alimentazione, Ambiente (Di3A), University of Catania, Via Santa Sofia 98, \\ 95123 Catania, Italy; sely81@hotmail.it (S.B.); bfallico@unict.it (B.F.) \\ * Correspondence: elena.arena@unict.it
}

Citation: Cincotta, F.; Brighina, S.; Condurso, C.; Arena, E.; Verzera, A.; Fallico, B. Sugars Replacement as a Strategy to Control the Formation of $\alpha$-Dicarbonyl and Furanic Compounds during Cookie Processing. Foods 2021, 10, 2101. https://doi.org/10.3390/ foods10092101

Academic Editor: Francisco J. Morales

Received: 26 July 2021

Accepted: 31 August 2021

Published: 5 September 2021

Publisher's Note: MDPI stays neutral with regard to jurisdictional claims in published maps and institutional affiliations.

Copyright: (c) 2021 by the authors. Licensee MDPI, Basel, Switzerland. This article is an open access article distributed under the terms and conditions of the Creative Commons Attribution (CC BY) license (https:// creativecommons.org/licenses/by/ $4.0 /)$.

\begin{abstract}
In the last decade, several preventive strategies were considered to mitigate the chemical hazard accumulation in food products. This work aimed to study the effect of different sugars on the development of the main chemical hazard in cookies. For this purpose, model biscuits prepared using sucrose, fructose, and glucose were baked at different temperatures $\left(150,170\right.$, and $\left.190{ }^{\circ} \mathrm{C}\right)$ and for different times (from 5 to $45 \mathrm{~min}$ ), and the levels of $\alpha$-dicarbonyl compounds, such as 3-deoxyglucosone (3-DG), glyoxal (GO) and methylglyoxal (MGO), 5-hydroxymethylfurfural (HMF), and furanic aromatic compounds were monitored. The replacement of sucrose in the cookie recipes with monosaccharides had as a consequence the highest accumulation of 3-DG (200-600 times higher), MGO, HMF, and furanic volatile compounds, while the use of sucrose allowed for maintaining the 3-DG, MGO, and HMF levels at less than $10 \mathrm{mg} / \mathrm{kg}$ dry matter in cookies for the estimated optimal baking time. Moreover, cookies with sucrose were characterised in terms of volatile compounds, mainly in terms of lipid oxidation products, while cookies with fructose or glucose baked at the highest temperature were characterised almost exclusively by Maillard reaction products, confirming a faster development of this reaction during baking at the studied temperatures.
\end{abstract}

Keywords: 3-deoxyglucosone; glyoxal; methylglyoxal; 5-hydroxymethylfurfural; Maillard reaction; furan; furan derivatives; headspace solid phase microextraction

\section{Introduction}

The Maillard reaction (MR) is an important and complex reaction that occurs in foods during thermal processing. It is responsible for the desirable aroma and colour development but also the undesirable chemical hazard formation.

In this regard, numerous studies have been undertaken about new chemical products that are formed during food processing due to safety concerns [1]. The main reported hazardous compounds are $\alpha$-dicarbonyl compounds (DCs), furan, 5-hydroxymethylfurfural (HMF), acrylamide, and heterocyclic amines [2].

DCs are intermediate compounds that are formed in thermally processed foods during the early stage of an MR, caramelisation reactions and lipid oxidation [3-8]. It is well known that baked goods and, in particular, cookies are an important dietary source of DCs since they contain high concentrations of sugars, have a low moisture content and are subject to baked conditions. The high variability of 3-deoxyglucosone (3-DG), glyoxal (GO), and methylglyoxal (MGO) levels was reported in commercial cookies [8-10]. The formation and degradation of DCs are strongly related to the colour and aroma development in food, as they are important precursors of both brown and volatile aromatic 
compounds [8,11]. Furthermore, DCs showed antibacterial activity against several bacteria strains [12-14]. Besides the beneficial role of DCs in foods, several adverse effects were reported both in vitro and in vivo. Cytotoxic activity and cancer-promoting effects were attributed to DCs $[8,15,16]$. Moreover, it was reported that DCs pass almost unaltered through the in vitro gastrointestinal digestion phases and strongly depressed the microbial community [17]. Moreover, DCs play a role as reactive precursors of the advanced glycation end products (AGEs), and the accumulation of both DCs and AGEs was associated with several chronic degenerative diseases, such as diabetes mellitus, Alzheimer's disease, cardiovascular disease, and atherosclerosis [18-21].

Furan and furan derivative compounds are formed in foods, mostly during heat processing, such as canning, cooking, baking, and roasting at 150 to $200{ }^{\circ} \mathrm{C}$ [22]. As such, they occur in several food items, such as coffee, baby foods, cereal, canned and jarred foods, meat, fish, and infant formula [23,24]. These compounds are derived from various natural precursors present in foods, including ascorbic acid, carbohydrates, amino acids, fatty acids, and carotenoids [23]. Furan was reported as being carcinogenic in animal models $[25,26]$ and is considered "possibly carcinogenic to humans" [27-29]. The highest exposures to furan were estimated for infants, mainly from ready-to-eat meals. Grains and grain-based products contribute most to the highest exposure to furan for toddlers, other children, and adolescents, and it is also the second-largest contributor in all other age classes [25].

HMF is a furanic compound that is formed during thermal treatments of foods as an intermediate of the MR and under acidic conditions from the sugar dehydration reaction [30]. It is present in several types of heat-treated commercial foods and it is used as a quality parameter in various processed food [31-37]. In cereals and baking items, HMF was used to monitor heating processes [38] and could be considered as the most important chemical contaminants that occur in bakery products [39].

It was reported that HMF lacks significant genotoxic activity, but it can be converted in vitro and in vivo into 5-sulfoxymethylfurfural (SMF), which was recognised to induce a genotoxic and mutagenic effect in bacterial and human cells and promote colon cancer in rats $[33,40,41]$.

In the last decade, several preventive strategies were considered to mitigate the chemical hazard accumulation in food products, such as changing the time/temperature profile of the heat treatment, varying the composition of the food matrix, and encapsulating the reactive compounds [2]. Removal interventions were also proposed [42,43].

This work aimed to study the effect of using different sugars and baking conditions on the main chemical hazard development in cookies. For this purpose, model biscuits that were prepared with different sugars, such as sucrose, fructose, and glucose, were baked for different times and temperature conditions, and the levels of 3-DG, GO, MGO, HMF, and aromatic volatiles, with particular attention to furanic compounds, were monitored.

\section{Materials and Methods}

\subsection{Standards and Chemicals}

High purity $(p>98 \%)$ 5-hydroxymethyl furfural (HMF), sucrose, fructose, glucose, o-phenylenediamine (OPD), glyoxal (GO) (40\% in water), and methylglyoxal (MGO) (40\% in water) were purchased from Sigma-Aldrich (St. Louis, MO, USA). 3-Deoxyglucosone (3-DG) $(p>95 \%)$ was purchased from Santa Cruz Biotechnology, Inc. (Santa Cruz, CA, USA). Methanol, acetic acid, and water were of HPLC grade and obtained from JT Baker (Deventer, Holland). Ethyl butanoate, 2-pentanone, hexanal, benzaldehyde, 1-hexanol, $\beta$-phenylethyl alcohol, limonene, 6-methyl-5-hepten-2-one, acetic acid, 2-methylpyrazine, furfural, acetyl furan, 5-methyl-furfural, and furfuryl alcohol were purchased from Merk (Milan, Italy).

Gemini NX C18 $(150 \mathrm{~mm} \times 4.6 \mathrm{~mm}, 5 \mu \mathrm{m})$ and Luna C18 $(250 \mathrm{~mm} \times 4.6 \mathrm{~mm}$, $5 \mu \mathrm{m}$ ) columns were obtained from Phenomenex (Torrance, CA, USA). A CP-Wax-52CB capillary column $(60 \mathrm{~m}, 0.25 \mathrm{~mm}$ i.d.; coating thickness $0.25 \mu \mathrm{m})$ and Divinylben- 
zene/Carboxen/Polydimethylsiloxane (DVB/CARB/PDMS) SPME fiber were obtained from Agilent Technologies (Santa Clara, CA, USA).

\subsection{Production of Cookies}

All ingredients, except for glucose, were purchased from local supermarkets. Model biscuits were prepared according to a recipe described in the American Association of Cereal Chemists (AACC) Method 10-54 (American Association of Cereal Chemists (AACC) International, 2000) with some modifications. The recipe was as follows: $240 \mathrm{~g}$ of wheat flour, $100.8 \mathrm{~g}$ of sucrose or fructose or glucose, $96 \mathrm{~g}$ of butter, $3 \mathrm{~g}$ of salt, $2.4 \mathrm{~g}$ of sodium bicarbonate, $1.2 \mathrm{~g}$ of ammonium bicarbonate, and $52.8 \mathrm{~mL}$ of deionised water.

According to the recipe, all the ingredients were thoroughly mixed using a dough mixer (model 1596, Ariete, Italy) for $7 \mathrm{~min}$. Afterwards, the dough was laminated three times using a manual laminator (Imperia, Lusso, sp 150 model, Bologna, Italy) and was formed into discs with a diameter of $5 \mathrm{~cm}$ and a thickness of $0.2 \mathrm{~cm}$. Seventy-five biscuits were produced from each batch of dough. Sucrose (SU)-, fructose (FR)-, and glucose (GL)formulated cookies were baked in a laboratory oven (ThermoScientific, Herathermoven, Italy) at three different temperatures: $150{ }^{\circ} \mathrm{C}, 170{ }^{\circ} \mathrm{C}$, and $190^{\circ} \mathrm{C}$ for up to $25 \mathrm{~min}$. The baking temperatures and times used in this study were set based on the cookies' thickness and colour development and were in the range suggested for short doughs [44]. Cookies were sampled every $5 \mathrm{~min}$ and used for estimating the optimal baking time. The dough and cooking processes were carried out in duplicates.

\subsection{Determination of the Estimated Optimal Baking Time (EOBT)}

The evaluation of the optimal surface colour of the cookies samples was performed by 50 panellists (age 20-55 years; 22 males, 28 females), who were habitual cookie consumers. The panelists choose to participate in the research and signed the informed consent as our institution does not have an ethics committee for taste and food quality evaluation studies. The evaluation was conducted in a room at $25{ }^{\circ} \mathrm{C}$ with white sidewalls and uniform light. Each panelist received for each cookie formulation (SU, FR, and GL) and baking temperatures $\left(150,170\right.$, and $\left.190^{\circ} \mathrm{C}\right)$, a randomly ordered set of cookies obtained at different baking time $(5,10,15,20,25 \mathrm{~min})$. The panellists were asked to indicate for each set the preferred baked good based on the surface colour of the cookies. These samples were selected for chemical characterisations. Moreover, the EOBT (in min) was calculated as the weighted arithmetic mean from the answers given by the panellists.

\subsection{Determination of the Moisture Content, $\mathrm{pH}$, and the Total Titratable Acidity}

The moisture content was determined in triplicate using gravimetric analysis. The cookie samples were ground in a home grinder (La Moulinette, Moulinex, Écully, France, 2002), then an aliquot of milled sample was placed in an oven at $105^{\circ} \mathrm{C}$ until the dry weight was constant [34].

The $\mathrm{pH}$ and the total titratable acidity (TTA) were measured on the ground samples according to [45] using a pH meter (Mettler Toledo, MP 220). The TTA results of the dry matter were expressed as millilitres of $0.1 \mathrm{M} \mathrm{NaOH}$ consumed to titrate to a final $\mathrm{pH}$ of 8.5, the suspension obtained by blending $10 \mathrm{~g}$ of sample with $90 \mathrm{~mL}$ distilled water.

All analyses were performed in triplicate, and the reported result of each analytical determination was the average of six values ( 2 sample replicates $\times 3$ analytical replicates).

\subsection{Dicarbonyl Compounds and HMF Extraction}

An aliquot of the milled sample ( $1 \mathrm{~g})$ (minced as described in Section 2.3) was transferred to a volumetric flask $(10 \mathrm{~mL})$ and $5 \mathrm{~mL}$ of deionised water was added. The solution was stirred for $10 \mathrm{~min}$, then the sample was diluted to $10 \mathrm{~mL}$ with deionised water and centrifuged at $10{ }^{\circ} \mathrm{C}$ for $15 \mathrm{~min}$ at $8500 \mathrm{rpm}$ (ALC 4128, Italy) [34]. An aliquot of the supernatant was filtered through a $0.45 \mu \mathrm{m}$ filter (Albet) and directly analysed to determine HMF content, while dicarbonyl compounds were derivatised before the HPLC analysis. 


\subsection{HMF Analysis}

An aliquot of the filtered supernatant was injected into an HPLC system (Shimadzu Class VP LC-10ADvp) equipped with a DAD (Shimadzu SPD-M10Avp). A Gemini NX C18 column fitted with a guard cartridge packed with the same stationary phase was used. The HPLC conditions were as follows: $0.1 \%(v / v)$ acetic acid in water $(94 \%)$ and methanol $(6 \%)$; flow rate, $0.7 \mathrm{~mL} / \mathrm{min}$; injection volume, $20 \mu \mathrm{L}$. The wavelength range was $220-660 \mathrm{~nm}$ and the chromatograms were monitored at $283 \mathrm{~nm}$ [34].

HMF was identified by comparing the retention times and UV spectra from samples with a standard solution and by splitting each sample with the HMF standard. Quantification of HMF was performed using external calibration curves. All analyses were performed in duplicate, including the extraction procedure, and the reported HMF concentration was therefore the average of eight values $(2$ sample replicates $\times 2$ extraction replicates $\times 2$ HPLC replicates). The results were expressed as milligrams of $\mathrm{HMF} /$ kilogram of biscuit dry matter.

\subsection{Determination of Dicarbonyl Compounds (3-DG, GO, and MGO)}

An aliquot of the filtered supernatant was derivatised with a $0.6 \%$ OPD solution in water [46]. After $12 \mathrm{~h}$, the derivatised mixture was injected into an HPLC (Spectra System) equipped with a diode array detector (UV6000LP) and an autosampler (AS3000) (Thermo Electron, San Jose, CA, USA). The HPLC column that was used was a Phenomenex Luna C18 and the HPLC conditions were as follows: eluent A was $0.1 \%(v / v)$ acetic acid in water and eluent $B$ was methanol; the flow rate was $0.7 \mathrm{~mL} / \mathrm{min}$; the injection volume was $20 \mu \mathrm{L}$. The gradient program was: t0 85\% A and $15 \% \mathrm{~B}, \mathrm{t} 1065 \% \mathrm{~A}$ and $35 \% \mathrm{~B}, \mathrm{t} 15 \mathrm{35} \% \mathrm{~A}$ and $65 \%$ $\mathrm{B}, \mathrm{t} 25 \mathrm{100} \% \mathrm{~B}$, and $\mathrm{t} 30 \mathrm{85} \% \mathrm{~A}$ and $15 \% \mathrm{~B}$. The detector wavelength was set to $312 \mathrm{~nm}$ [14]. All compounds were identified by comparing the retention times and UV spectra with those of standard solutions and by spiking each sample with standards (GO, Sigma Aldrich, 43612, 40\% in water; MGO, Sigma, M0252, 40\% in water; 3-DG; Santa Cruz Biotechnology, sc-220865, $10 \mathrm{mg}, p>95 \%$ ). Quantification of each component was performed using external calibration curves. The extraction procedure and the analyses were performed in duplicate, the reported concentration of each dicarbonyl compound was therefore the average of eight values ( 2 sample replicates $\times 2$ extraction replicates $\times 2$ HPLC replicates). The results were expressed as milligrams of dicarbonyl compound/kilogram of biscuit dry matter.

\subsection{Determination of Aromatic Compounds}

The volatile aromatic compounds in the cookie samples were analysed at the EOBT using Headspace Solid Phase Microextraction Gas Chromatography-Mass Spectrometry (HS-SPME-GC-MS). An SPME fiber that was coated with Divinylbenzene/Carboxen/ Polydimethylsiloxane (DVB/CARB/PDMS) was used for the extraction of volatile aromatic compounds. A total of $1.5 \mathrm{~g}$ of homogenised milled sample were inserted into a $7 \mathrm{~mL}$ glass vial and added with $2 \mathrm{~mL}$ of saturated aqueous $\mathrm{NaCl}$ solution. The sample was equilibrated for $15 \mathrm{~min}$ at $35^{\circ} \mathrm{C}$, thus the fiber was exposed to the headspace for $15 \mathrm{~min}$. Afterwards, the fiber was withdrawn into the needle and transferred to the injection port of the GC at $260^{\circ} \mathrm{C}$ and kept for $3 \mathrm{~min}$ for the thermal desorption of the analytes onto the capillary GC capillary column.

The GC-MS analyses were performed using a Shimadzu GC 2010 Plus gas chromatograph that interfaced with a TQMS 8040 triple quadrupole mass spectrometer (Shimadzu, Milan, Italy) that was equipped with a CP-Wax-52-CB capillary column $(60 \mathrm{~m}, 0.25 \mathrm{~mm}$ i.d.; coating thickness, $0.25 \mu \mathrm{m}$ ). The analysis conditions were as follows: injector temperature, $260^{\circ} \mathrm{C}$; injection mode, splitless; oven temperature, $50^{\circ} \mathrm{C}$ held for $5 \mathrm{~min}$, then increased to $190^{\circ} \mathrm{C}$ at a rate of $3{ }^{\circ} \mathrm{C} / \mathrm{min}$, and to $240^{\circ} \mathrm{C}$ at $6{ }^{\circ} \mathrm{C} / \mathrm{min}$; carrier gas, helium used at a constant pressure of $10 \mathrm{psi}$; transfer line temperature, $250^{\circ} \mathrm{C}$; acquisition range, $40-400 \mathrm{~m} / \mathrm{z}$; scan speed, $1250 \mathrm{amu} / \mathrm{s}$.

Each compound was identified using mass spectral data, NIST'20 (NIST/EPA/NIH Mass Spectra Library, Wiley, Hoboken, NJ, USA) and the FFNSC 3.0 database, linear 
retention indices (LRI), literature data, and the injection of the available standards. LRIs were determined based on a homologous n-alkane hydrocarbon mixture and analysed under the same GC conditions; LRIs were calculated according to Van den Dool and Kratz equation [47].

The volatile compounds were quantified using the standard addition method. Stock solutions of individual standards were prepared by dissolving the appropriate amount of each compound in ethyl alcohol (95\%) to obtain a final concentration of $0.2 \mathrm{mg} / \mathrm{mL}$. The solutions were stored at under $-30{ }^{\circ} \mathrm{C}$. Furthermore, five different volumes of each stock solution were added to multiple aliquots of each sample. The sample alone was also analysed. Quantification was based on a calibration curve that was generated by plotting the detector response versus the amount spiked of each standard. The peak area of each compound was determined during three replicates and the average value was calculated.

To quantify compounds, the calibration curve of a compound of the same class of substances with the most similar chemical structure and retention time was used.

Each sample was analysed in triplicate.

\subsection{Statistical Analysis}

Data for each chemical parameter were submitted to an ANOVA (SPSS ${ }^{\circledR}$ Statistics 13.0, Armonk, NY, USA) to evaluate the significant differences $(p<0.05)$ within samples baked at the same temperature and for the same time.

Microsoft XLstat software 2014 (Addinsoft, Paris, France) was used to perform the statistical analysis of the volatile data. ANOVA, Tukey's test, and principal component analysis (PCA) were performed to understand the statistically significant differences and investigate the relationship between sugar formulations, baking conditions, and aroma volatiles. A heat map was generated to visualise the clustering of the multivariate data.

\section{Results and Discussion}

\subsection{Effect of Sugars on Optimal Baking Time and Chemical Properties of Cookies}

Finding the optimal baking time (EOBT) for cookies is generally performed to achieve the desired surface colour $[48,49]$. Table 1 reports the EOBT at each temperature. At $150{ }^{\circ} \mathrm{C}$, the EOBT was 21.3, 24.5, and $25 \mathrm{~min}$ for cookies prepared with glucose (GL), fructose (FR), and sucrose (SU), respectively. At $170{ }^{\circ} \mathrm{C}$, the EOBT was about $20 \mathrm{~min}$ for all cookie formulations. At the higher baking temperatures, the differences between the EOBT values were lower. The increases in baking temperature from 150 to $170{ }^{\circ} \mathrm{C}$ and from 170 to $190{ }^{\circ} \mathrm{C}$ each took a progressive reduction of about $5 \mathrm{~min}$ off the EOBT for SU and FR cookies and 3-4 min for GL cookie samples. GL had the lowest EOBT due to a more intense surface colouration.

Table 1. Estimated optimal baking time (EOBT) in minutes of cookies produced using different sugars.

\begin{tabular}{|c|c|c|c|c|c|c|c|c|c|}
\hline \multirow{2}{*}{ Temperature } & \multicolumn{3}{|c|}{ SU Cookies } & \multicolumn{3}{|c|}{ FR Cookies } & \multicolumn{3}{|c|}{ GL Cookies } \\
\hline & Time $^{1}$ & Frequency & EOBT & Time $^{1}$ & Frequency & EOBT & Time $^{1}$ & Frequency & EOBT \\
\hline \multirow{2}{*}{150} & \multirow{2}{*}{25} & \multirow{2}{*}{$100 \%$} & \multirow{2}{*}{25} & 20 & $10 \%$ & \multirow{2}{*}{24.5} & 20 & $75 \%$ & \multirow{2}{*}{21.3} \\
\hline & & & & 25 & $90 \%$ & & 25 & $25 \%$ & \\
\hline \multirow{2}{*}{170} & \multirow{2}{*}{20} & \multirow{2}{*}{$100 \%$} & \multirow{2}{*}{20} & 15 & $10 \%$ & \multirow{2}{*}{19.5} & 15 & $30 \%$ & \multirow{2}{*}{18.5} \\
\hline & & & & 20 & $90 \%$ & & 20 & $70 \%$ & \\
\hline \multirow{2}{*}{190} & 15 & $90 \%$ & \multirow{2}{*}{15.5} & \multirow{2}{*}{15} & \multirow{2}{*}{$100 \%$} & \multirow{2}{*}{15} & 10 & $20 \%$ & \multirow{2}{*}{14} \\
\hline & 20 & $10 \%$ & & & & & 15 & $80 \%$ & \\
\hline
\end{tabular}

SU cookies: cookies formulated with sucrose; FR cookies: cookies formulated with fructose; GL cookies: cookies formulated with glucose.

${ }^{1}$ minutes.

According to our EOBT trend, it was found that cookies formulated with sucrose needed more baking time to reach a similar browning level than cookies formulated with hexose [50]. 
Cookies that had a baking time near the EOBT were sampled and analysed to determine the moisture content, $\mathrm{pH}$ and TTA, HMF, dicarbonyl compounds, and aroma volatile compounds.

Sugar type, temperature, and time for the baking process had strong effects on the measured parameters (Table 2 ).

Table 2. Chemical parameters of cookie samples as a function of the type of sugar, baking time, and temperature.

\begin{tabular}{|c|c|c|c|c|c|c|c|c|c|}
\hline \multirow{2}{*}{ Parameters } & \multicolumn{3}{|c|}{ SU Cookies } & \multicolumn{3}{|c|}{ FR Cookies } & \multicolumn{3}{|c|}{ GL Cookies } \\
\hline & $\begin{array}{l}150^{\circ} \mathrm{C} \\
25 \mathrm{~min}\end{array}$ & $\begin{array}{l}170^{\circ} \mathrm{C} \\
20 \mathrm{~min}\end{array}$ & $190^{\circ} \mathrm{C}$ & $150^{\circ} \mathrm{C}$ & $170^{\circ} \mathrm{C}$ & $190^{\circ} \mathrm{C}$ & $150^{\circ} \mathrm{C}$ & $170^{\circ} \mathrm{C}$ & $190^{\circ} \mathrm{C}$ \\
\hline Moisture ${ }^{1}$ & $2.0+0.3 c$ & $2.3+0.4 c$ & $4.2+0.7 \mathrm{~b}$ & $6.1+0.5 b$ & $6.2+0.3 a$ & $6.3+0.3 a$ & $7.9+0.6 a$ & $4.9+0.2 b$ & $5.5+0.6 a$ \\
\hline $\mathrm{pH}$ & $7.1 \pm 0.02 a$ & $7.2 \pm 0.08 \mathrm{a}$ & $7.2 \pm 0.04 a$ & $6.5 \pm 0.02 b$ & $6.4 \pm 0.12 b$ & $6.4 \pm 0.10 b$ & $6.9 \pm 0.13 b$ & $6.5 \pm 0.16 b$ & $6.6 \pm 0.09 b$ \\
\hline TTA $^{2}$ & $1.7 \pm 0.1 \mathrm{~b}$ & $1.7 \pm 0.1 \mathrm{~b}$ & $1.6 \pm 0.1 \mathrm{~b}$ & $4.0 \pm 0.0 \mathrm{a}$ & $4.4 \pm 0.4 a$ & $4.0 \pm 0.3 a$ & $2.6 \pm 0.1 b$ & $3.7 \pm 0.1 \mathrm{a}$ & $3.7 \pm 0.1 \mathrm{a}$ \\
\hline $\mathrm{HMF}^{3}$ & $5.1 \pm 0.9 b$ & $5.2 \pm 1.5 c$ & $8.3 \pm 0.4 b$ & $10.4 \pm 1.6 \mathrm{a}$ & $74.9 \pm 5.3 a$ & $22.2 \pm 7.1 \mathrm{a}$ & $4.5 \pm 1.0 \mathrm{~b}$ & $14.9 \pm 1.9 b$ & $23.5 \pm 3.2 \mathrm{a}$ \\
\hline $3-\mathrm{DG}^{3}$ & $6.7 \pm 1.7 c$ & $6.1 \pm 1.3 c$ & $5.3 \pm 1.3 c$ & $1038.8 \pm 133.0 \mathrm{~b}$ & $1162.3 \pm 188.5 b$ & $960.9 \pm 119.4 b$ & $2113.9 \pm 384.6 \mathrm{a}$ & $3517.9 \pm 206.0 \mathrm{a}$ & $3250.3 \pm 54.7 a$ \\
\hline $\mathrm{GO}^{3}$ & $10.7 \pm 0.4 \mathrm{~b}$ & $10.3 \pm 0.6 \mathrm{a}$ & $10.7 \pm 0.4 \mathrm{a}$ & $14.5 \pm 1.8 \mathrm{a}$ & $16.0 \pm 2.3 a$ & $14.1 \pm 1.5 \mathrm{a}$ & $14.3 \pm 3.2 \mathrm{a}$ & $15.4 \pm 4.0 \mathrm{a}$ & $15.6 \pm 4.1 \mathrm{a}$ \\
\hline $\mathrm{MGO}^{3}$ & $8.4 \pm 0.3 c$ & $8.3 \pm 0.4 c$ & $8.40 \pm 0.3 c$ & $33.5 \pm 0.9 a$ & $39.8 \pm 2.1 \mathrm{a}$ & $37.5 \pm 2.1 \mathrm{a}$ & $11.8 \pm 0.8 b$ & $17.3 \pm 1.3 b$ & $18.7 \pm 0.8 b$ \\
\hline
\end{tabular}

SU cookies: cookies formulated with sucrose; FR cookies: cookies formulated with fructose; GL cookies: cookies formulated with glucose. ${ }^{1} \mathrm{~g} / 100 \mathrm{~g} .{ }^{2}$ total titratable acidity expressed as $\mathrm{mL} \mathrm{NaOH} \mathrm{N} / 10$ on dry matter. ${ }^{3} \mathrm{mg} / \mathrm{kg}$ dry matter. Data expressed as the mean \pm standard deviation. Different letters in the same row indicate significant differences at $p<0.05$ between cookie formulations with the respective temperatures and baking times.

The first difference was that the SU cookies had the lowest moisture content independent of the baking temperature and time (about $2 \%$ at $150-170{ }^{\circ} \mathrm{C}$ and $4 \%$ at $190{ }^{\circ} \mathrm{C}$ ), suggesting a faster loss of water during baking. The FR samples baked at $150^{\circ}$ and $170{ }^{\circ} \mathrm{C}$ had triple the moisture content (about 6\%) relative to the SU cookies. The GL cookies baked at $150{ }^{\circ} \mathrm{C}$ had the highest moisture level (about $8 \%$ ), probably due to the shorter baking time $(20 \mathrm{~min})$; when the GL cookies were baked at $170{ }^{\circ} \mathrm{C}$, the moisture content was significantly different from the levels determined in the other cookies (Table 2). At the highest baking temperature, the GL and FR cookies had a similar moisture level. No significant differences were reported regarding the water loss between cookies produced with different types of sugars and cooked at the highest temperature $\left(200-300{ }^{\circ} \mathrm{C}\right)$ [50].

Differences were also apparent for both $\mathrm{pH}$ and titratable acidity values (Table 2). Furthermore, in this case, the SU samples were significantly different from the other cookie samples independent of the baking temperature, recording the highest $\mathrm{pH}$ value and the lowest titratable acidity (Table 2). This trend was due to the lower reactivity of sucrose to the MR than monosaccharides. The FR and GL samples showed similar values for both $\mathrm{pH}$ and titratable acidity at different baking temperatures (Table 2).

As concerns HMF and 1,2-dicarbonyl compound levels, significant differences were found between samples (Table 2). The levels of HMF were in a similar range $(5-75 \mathrm{mg} / \mathrm{kg})$ to that found in a survey of commercial cookies [7,51]. Generally, increasing the baking temperature increased the HMF levels in cookies. The HMF amount was lower in the cookies where sucrose was used as a sweetener in comparison with those containing fructose or glucose due to the necessary sucrose hydrolysis into monosaccharides before HMF formation [50,52]. In the SU samples, the HMF levels ranged from about 5.1 to $8.3 \mathrm{mg} / \mathrm{kg}$ in the samples cooked at 150 and $190{ }^{\circ} \mathrm{C}$, respectively. It was reported that under an oven temperature of $300{ }^{\circ} \mathrm{C}$, cookies with sucrose were associated with the lowest $\mathrm{HMF}$ accumulation rate, while at $300{ }^{\circ} \mathrm{C}$, an inverse trend was found, in agreement with the drastic sucrose degradation [50]. The use of fructose brought about the highest levels of HMF, both at 150 and $170{ }^{\circ} \mathrm{C}(10.4$ and $74.9 \mathrm{mg} / \mathrm{kg}$, respectively), as the rate of fructose conversion into the first intermediate was the highest [52]. The GL cookies showed a different trend: at $150^{\circ} \mathrm{C}$, the samples had an HMF content that was similar to that found in the SU cookies $(4.5 \mathrm{mg} / \mathrm{kg})$, notwithstanding a shorter baking time; at $170{ }^{\circ} \mathrm{C}$ samples had an HMF content that was higher than the SU cookies and lower relative to the FR ones. These trends agreed with those reported by $[50,53,54]$. At the highest temperature, the cookies with monosaccharides showed similar HMF contents (about $22-23 \mathrm{mg} / \mathrm{kg}$ ). The use of sucrose and the used baking temperatures allowed for maintaining the HMF level at less than $5 \mathrm{mg} / \mathrm{kg}$ dry matter in cookies at the EOBT. 
The substitution of sucrose with fructose or glucose drastically affected the production of the three DCs, 3-DG, GO, and MGO, particularly 3-DG (Table 2). The SU samples contained very low levels of 3-DG, ranging from 5.3 to $6.7 \mathrm{mg} / \mathrm{kg}$. These amounts were lower relative to the range reported by [10] and similar to those reported for commercial cookies [7]. In cookies with monosaccharides (FR and GL), 3-DG was the major dicarbonyl and its concentrations ranged from 960.9 to $3517.9 \mathrm{mg} / \mathrm{kg}$ for the FR cookies baked at $190{ }^{\circ} \mathrm{C}$ and the GL cookies baked at $170^{\circ} \mathrm{C}$, respectively. The use of glucose or fructose brought about an accumulation of 3-DG that was as much as 200-600 times higher relative to the sample with sucrose. Higher concentrations of 3-DG and the other $\alpha$-dicarbonyls were found in cookies containing fructose/glucose syrup [10]. Moreover, between the two monosaccharides, GL cookies had the highest levels of 3-DG, ranging from about 2113 to $3517 \mathrm{mg} / \mathrm{kg}$ dry matter.

GO is a dicarbonyl compound that is mainly produced by the autoxidation of glucose [55], and MGO is formed by the retroaldolisation of the intermediate 3-deoxyglucosulose [56].

At the EOBT, the GO levels ranged from 10.3 to $16 \mathrm{mg} / \mathrm{kg}$ dry matter and no significant differences were found between the samples for all baking temperatures. A range of $4.8-20.5 \mathrm{mg} / \mathrm{kg}$ of GO was reported in commercial cookies and a lower level of GO was found in cookies that were prepared at the laboratory scale due to both the different baking processes and the type of sugar used in the formulation [9]. Moreover, in the SU cookies, the amount of GO was higher than of MGO, while in the FR and GL cookies, the MGO concentration was generally higher than for GO. This different behaviour was probably due to the different formation pathways: GO is formed via sugar oxidation during the heating process, unlike MGO, which is enhanced by the MR [9].

As concerns MGO, its level ranged from 8.3 to $39.8 \mathrm{mg} / \mathrm{kg}$. The substitution in the recipe of sucrose with the monosaccharides led to an increase in MGO. In the SU cookies, MGO was about $8 \mathrm{mg} / \mathrm{kg}$, independent of the baking temperature. In the GL cookies, the MGO amount was between 11.8 and $18.7 \mathrm{mg} / \mathrm{kg}$. The MGO concentration was the highest in cookies with fructose, with a level ranging from 33.5 to $39.8 \mathrm{mg} / \mathrm{kg}$ dry matter (Table 2). Cookies with monosaccharides had the highest levels of HMF, 3-DG, and MGO, confirming that MGO was enhanced by the MR [9]. Different levels of MGO were found in commercial cookies, depending on the type of sugars used in the formulation, the baking temperature and time, and the presence of other ingredients [9,10]. Moreover, the lowest levels of MGO and acrylamide were found in cookies that contained ingredients such as sucrose, glucose, or sodium bicarbonate [9].

Thus, it is possible to produce cookies with the lowest levels of HMF and DCs but with the desired surface colour by using sucrose in the recipe and baking them at the optimal temperature and time.

\subsection{Effect of Sugar Substitution on Aroma Volatile Compounds of Cookies}

Table 3 reports the volatile compounds that were identified using HS-SPME-GC-MS in cookies from different sugar formulations at the EOBT, along with odour descriptors and their tentative origins. The analyses that were carried out allowed for identifying a large number of volatile aromatic compounds, of which, 37 had a signal-to-noise ratio higher than 10, and hence were quantifiable. Esters, ketones, aldehydes, alcohols, terpenes, $\mathrm{C}_{13}$-norisoprenoids, acids, pyrazines, and furanic compounds were identified. 
Table 3. Volatile aromatic compounds (ng/g) in cookies at the EOBT using different sugar formulations.

\begin{tabular}{|c|c|c|c|c|c|c|c|c|c|c|c|c|}
\hline \multirow[b]{2}{*}{ Compounds } & \multirow[b]{2}{*}{ LRI } & \multirow[b]{2}{*}{$\begin{array}{c}\text { Odour } \\
\text { Description }\end{array}$} & \multirow[b]{2}{*}{$\begin{array}{c}\text { Tentative } \\
\text { Origin }\end{array}$} & \multicolumn{3}{|c|}{ SU Cookies } & \multicolumn{3}{|c|}{ FR Cookies } & \multicolumn{3}{|c|}{ GL Cookies } \\
\hline & & & & $\begin{array}{l}150^{\circ} \mathrm{C} \\
25 \mathrm{~min}\end{array}$ & $\begin{array}{l}170^{\circ} \mathrm{C} \\
20 \mathrm{~min}\end{array}$ & $\begin{array}{l}190^{\circ} \mathrm{C} \\
15 \mathrm{~min}\end{array}$ & $\begin{array}{l}150^{\circ} \mathrm{C} \\
25 \mathrm{~min}\end{array}$ & $\begin{array}{l}170^{\circ} \mathrm{C} \\
20 \mathrm{~min}\end{array}$ & $\begin{array}{l}190^{\circ} \mathrm{C} \\
15 \mathrm{~min}\end{array}$ & $\begin{array}{l}150^{\circ} \mathrm{C} \\
20 \mathrm{~min}\end{array}$ & $\begin{array}{l}170^{\circ} \mathrm{C} \\
20 \mathrm{~min}\end{array}$ & $\begin{array}{l}190^{\circ} \mathrm{C} \\
15 \text { min }\end{array}$ \\
\hline \multicolumn{13}{|l|}{ Esters } \\
\hline Ethyl butanoate & 1037 & Fruity, sweet, apple & LO & $11.72 \mathrm{a}$ & $4.25 c$ & $3.54 \mathrm{c}$ & $13.50 \mathrm{a}$ & $6.38 \mathrm{~b}$ & $4.61 c$ & $7.45 \mathrm{~b}$ & $7.09 \mathrm{~b}$ & $3.89 c$ \\
\hline Ethyl octanoate & 1437 & Fruity, wine, waxy & $\mathrm{LO}$ & $18.83 a$ & $12.78 \mathrm{~b}$ & $13.50 \mathrm{~b}$ & $23.10 \mathrm{a}$ & $24.52 \mathrm{a}$ & $16.34 b$ & $27.36 a$ & 19.19a & $13.14 \mathrm{~b}$ \\
\hline Total & & & & 30.55 & 17.03 & 17.04 & 36.60 & 30.90 & 20.95 & 34.81 & 26.28 & 17.03 \\
\hline \multicolumn{13}{|l|}{ Ketones } \\
\hline Diacetyl & 1062 & Buttery, sweet, creamy & MR & nd c & $2.47 \mathrm{~b}$ & $4.25 \mathrm{~b}$ & $6.38 b$ & $8.87 \mathrm{a}$ & $12.43 a$ & $3.18 b$ & $2.12 b$ & $7.45 a$ \\
\hline 2-Heptanone & 1168 & Fruity, spicy, sweet, herbal & $\mathrm{LO}$ & $222.24 b$ & $245.36 b$ & $292.66 a$ & $235.05 b$ & $216.55 b$ & $192.02 b$ & $285.19 a$ & $129.07 \mathrm{c}$ & $107.73 \mathrm{c}$ \\
\hline Acetoin & 1290 & Sweet, buttery, creamy, dairy & MR & $13.14 \mathrm{c}$ & $10.65 c$ & $9.94 c$ & $37.32 b$ & $30.57 \mathrm{~b}$ & $32.34 b$ & $56.88 \mathrm{a}$ & $33.77 \mathrm{~b}$ & $29.14 b$ \\
\hline 2-Nonanone & 1394 & Roasty, cake crust, sweet & $\mathrm{LO}$ & $92.09 \mathrm{a}$ & $110.94 \mathrm{a}$ & $112.00 \mathrm{a}$ & $70.04 \mathrm{~b}$ & $82.84 \mathrm{~b}$ & $78.93 b$ & $87.11 b$ & $81.77 \mathrm{~b}$ & $68.26 \mathrm{~b}$ \\
\hline 4-cyclopentene-1,3-dione & 1598 & & MR & nd c & $14.56 \mathrm{~b}$ & $10.65 b$ & $4.25 \mathrm{~b}$ & $13.85 \mathrm{~b}$ & $33.05 a$ & $7.45 b$ & $12.43 b$ & $40.52 \mathrm{a}$ \\
\hline 2-Undecanone & 1605 & Waxy, fruity, creamy, fatty & $\mathrm{LO}$ & $19.19 \mathrm{a}$ & $17.76 a$ & $15.27 \mathrm{a}$ & $17.76 a$ & $20.96 a$ & $17.05 \mathrm{a}$ & $23.10 \mathrm{a}$ & $22.74 a$ & $14.92 \mathrm{a}$ \\
\hline Total & & & & 364.42 & 424.84 & 466.44 & 428.04 & 425.19 & 411.68 & 576.33 & 361.90 & 300.01 \\
\hline \multicolumn{13}{|l|}{ Aldheydes } \\
\hline Hexanal & 1089 & Green, fatty, leafy & $\mathrm{LO}$ & $84.26 \mathrm{~b}$ & $86.75 b$ & $106.31 b$ & $112.36 \mathrm{~b}$ & $93.15 b$ & $99.20 \mathrm{~b}$ & $200.20 a$ & $195.93 a$ & $118.05 \mathrm{~b}$ \\
\hline Octanal & 1294 & Aldehydic, waxy, citrus & $\mathrm{LO}$ & $10.30 \mathrm{~b}$ & $11.72 \mathrm{~b}$ & $18.83 a$ & $7.45 b$ & $8.16 \mathrm{~b}$ & $8.52 b$ & $10.30 \mathrm{~b}$ & $9.58 b$ & $10.65 b$ \\
\hline (E)-2-Heptenal & 1329 & Pungent, green, vegetable & $\mathrm{LO}$ & $2.47 \mathrm{~b}$ & $12.43 \mathrm{a}$ & $15.27 \mathrm{a}$ & $0.34 \mathrm{~b}$ & $6.74 \mathrm{~b}$ & $9.58 \mathrm{a}$ & $8.87 \mathrm{a}$ & $11.01 \mathrm{a}$ & $4.25 \mathrm{~b}$ \\
\hline Nonanal & 1400 & Bready, cake crust & $\mathrm{LO}$ & $33.05 a$ & $44.79 \mathrm{a}$ & $55.10 \mathrm{a}$ & $36.61 \mathrm{a}$ & $38.74 a$ & $33.41 \mathrm{a}$ & $56.53 a$ & $44.79 \mathrm{a}$ & $40.88 \mathrm{a}$ \\
\hline (E)-2-Octenal & 1425 & Damp, earthy & $\mathrm{LO}$ & $6.38 \mathrm{c}$ & $10.65 c$ & $9.23 c$ & $8.52 \mathrm{c}$ & $11.36 \mathrm{c}$ & $11.01 \mathrm{c}$ & $65.42 \mathrm{a}$ & $37.32 b$ & $18.83 \mathrm{c}$ \\
\hline Benzaldehyde & 1532 & Sweet & MR/LO & $18.12 b$ & $26.30 \mathrm{~b}$ & $28.43 b$ & $57.95 \mathrm{a}$ & $56.17 \mathrm{a}$ & $53.68 \mathrm{a}$ & $52.26 a$ & $51.90 \mathrm{a}$ & $44.08 \mathrm{a}$ \\
\hline 4-Ethyl-benzaldehyde & 1729 & Almond, sweet & MR & $6.74 \mathrm{~b}$ & $7.45 \mathrm{~b}$ & $12.78 \mathrm{a}$ & $10.30 \mathrm{a}$ & $11.72 \mathrm{a}$ & $15.63 a$ & $9.94 a$ & $12.78 \mathrm{a}$ & $14.92 \mathrm{a}$ \\
\hline Total & & & & 243.09 & 237.41 & 267.98 & 297.17 & 259.45 & 248.08 & 468.58 & 400.28 & 268.36 \\
\hline \multicolumn{13}{|l|}{ Alcohols } \\
\hline Pentanol & 1242 & Fusel oil, sweet balsamic & $\mathrm{LO}$ & $11.01 \mathrm{~b}$ & $12.07 \mathrm{~b}$ & $12.43 \mathrm{~b}$ & $11.01 \mathrm{~b}$ & $13.50 \mathrm{~b}$ & $13.14 b$ & $19.90 \mathrm{a}$ & $17.05 \mathrm{a}$ & $12.78 \mathrm{~b}$ \\
\hline 1-Hexanol & 1355 & Ethereal, fusel oil, fruity & $\mathrm{LO}$ & $12.43 \mathrm{~b}$ & $11.36 \mathrm{~b}$ & $10.65 b$ & $9.58 b$ & $11.72 b$ & $9.94 b$ & $17.76 \mathrm{a}$ & $11.01 \mathrm{~b}$ & $5.32 \mathrm{~b}$ \\
\hline Diacetone alcohol & 1368 & & MR & $3.54 \mathrm{~d}$ & $85.69 \mathrm{c}$ & $161.43 b$ & $22.39 \mathrm{~d}$ & $207.66 a$ & $205.89 a$ & $3.54 \mathrm{~d}$ & $213.71 \mathrm{a}$ & $224.73 a$ \\
\hline 2-Ethyl-1-Hexanol & 1489 & Citrus, fresh, floral, oily & $\mathrm{LO}$ & $14.92 \mathrm{a}$ & $14.56 \mathrm{a}$ & $15.27 \mathrm{a}$ & $15.63 a$ & $14.92 \mathrm{a}$ & $14.21 \mathrm{a}$ & $20.96 a$ & $19.90 \mathrm{a}$ & $13.14 \mathrm{a}$ \\
\hline$\beta$-Phenylethyl alcohol & 1919 & Rose, honey-like & MR & $9.23 \mathrm{~b}$ & $7.81 \mathrm{~b}$ & $4.96 c$ & $7.81 \mathrm{~b}$ & $10.30 \mathrm{~b}$ & $8.52 b$ & $15.27 \mathrm{a}$ & $14.21 \mathrm{a}$ & $6.03 b$ \\
\hline Phenol & 2003 & Phenolic, plastic & & $8.52 a$ & $9.94 a$ & $11.36 a$ & $3.89 \mathrm{~b}$ & $6.03 b$ & $4.96 \mathrm{~b}$ & $4.61 \mathrm{~b}$ & $6.03 \mathrm{~b}$ & $5.32 \mathrm{~b}$ \\
\hline Total & & & & 59.65 & 141.43 & 216.10 & 70.31 & 264.13 & 256.66 & 82.04 & 281.91 & 267.32 \\
\hline
\end{tabular}


Table 3. Cont

\begin{tabular}{|c|c|c|c|c|c|c|c|c|c|c|c|c|}
\hline \multirow[b]{2}{*}{ Compounds } & \multirow[b]{2}{*}{ LRI } & \multirow[b]{2}{*}{$\begin{array}{c}\text { Odour } \\
\text { Description }\end{array}$} & \multirow[b]{2}{*}{$\begin{array}{l}\text { Tentative } \\
\text { Origin }\end{array}$} & \multicolumn{3}{|c|}{ SU Cookies } & \multicolumn{3}{|c|}{ FR Cookies } & \multicolumn{3}{|c|}{ GL Cookies } \\
\hline & & & & $\begin{array}{l}150{ }^{\circ} \mathrm{C} \\
25 \mathrm{~min}\end{array}$ & $\begin{array}{l}170{ }^{\circ} \mathrm{C} \\
20 \mathrm{~min}\end{array}$ & $\begin{array}{l}190^{\circ} \mathrm{C} \\
15 \text { min }\end{array}$ & $\begin{array}{l}150{ }^{\circ} \mathrm{C} \\
25 \mathrm{~min}\end{array}$ & $\begin{array}{l}170^{\circ} \mathrm{C} \\
20 \mathrm{~min}\end{array}$ & $\begin{array}{l}190^{\circ} \mathrm{C} \\
15 \mathrm{~min}\end{array}$ & $\begin{array}{l}150{ }^{\circ} \mathrm{C} \\
20 \mathrm{~min}\end{array}$ & $\begin{array}{l}170^{\circ} \mathrm{C} \\
20 \mathrm{~min}\end{array}$ & $\begin{array}{l}190{ }^{\circ} \mathrm{C} \\
15 \mathrm{~min}\end{array}$ \\
\hline $\begin{array}{l}\text { Terpenes } \\
\text { Limonene }\end{array}$ & 1183 & Citrus, lemon & & $10.30 \mathrm{~b}$ & $12.07 \mathrm{a}$ & $12.78 \mathrm{a}$ & $6.74 \mathrm{c}$ & $8.16 \mathrm{c}$ & $6.03 c$ & $14.21 \mathrm{a}$ & $10.30 \mathrm{~b}$ & $5.67 \mathrm{c}$ \\
\hline $\begin{array}{l}\mathrm{C}_{13} \text {-Norisoprenoids } \\
\text { 4-Methyl-3-penten-2-one } \\
\text { 6-Methyl-5-hepten-2-one } \\
\text { (E)-Geranyl acetone } \\
\text { Total }\end{array}$ & $\begin{array}{l}1129 \\
1340 \\
1862\end{array}$ & $\begin{array}{l}\text { Musty, nutty chocolate } \\
\text { Fruity, musty apple } \\
\text { Fresh, rose, leafy, floral }\end{array}$ & & $\begin{array}{c}20.25 a \\
9.23 b \\
\text { nd c } \\
29.48\end{array}$ & $\begin{array}{c}7.09 \mathrm{~b} \\
13.85 \mathrm{a} \\
19.90 \mathrm{a} \\
\mathbf{4 0 . 8 4}\end{array}$ & $\begin{array}{c}5.67 \mathrm{~b} \\
12.78 \mathrm{a} \\
23.81 \mathrm{a} \\
\mathbf{4 2 . 2 6}\end{array}$ & $\begin{array}{l}1.05 \mathrm{c} \\
4.25 \mathrm{c} \\
5.67 \mathrm{~b} \\
\mathbf{1 0 . 9 7}\end{array}$ & $\begin{array}{l}6.03 b \\
2.83 c \\
7.81 b \\
16.67\end{array}$ & $\begin{array}{l}9.58 b \\
5.32 \mathrm{c} \\
7.09 \mathrm{~b} \\
\mathbf{2 1 . 9 9}\end{array}$ & $\begin{array}{c}\text { nd d } \\
7.09 \mathrm{~b} \\
14.21 \mathrm{a} \\
\mathbf{2 1 . 3}\end{array}$ & $\begin{array}{c}\text { nd d } \\
7.81 \mathrm{~b} \\
19.19 \mathrm{a} \\
\mathbf{2 7 . 0 0}\end{array}$ & $\begin{array}{l}\text { nd d } \\
6.38 \mathrm{~b} \\
\text { nd c } \\
6.38\end{array}$ \\
\hline $\begin{array}{c}\text { Acids } \\
\text { Acetic acid }\end{array}$ & 1464 & Pungent, sour, vinegar & MR, C & $1.40 \mathrm{c}$ & $13.85 \mathrm{~b}$ & $12.43 \mathrm{~b}$ & $14.92 \mathrm{~b}$ & $17.41 \mathrm{~b}$ & $31.28 \mathrm{a}$ & $12.07 \mathrm{~b}$ & $15.99 b$ & $19.54 b$ \\
\hline $\begin{array}{c}\text { Pyrazines } \\
\text { 2-Methylpyrazine }\end{array}$ & 1269 & Roasted, burnt, sweet & $\mathrm{MR} / \mathrm{LO}$ & $2.47 \mathrm{c}$ & $5.32 b$ & $7.09 a$ & $3.18 b$ & $4.25 \mathrm{~b}$ & $4.25 \mathrm{~b}$ & $4.25 \mathrm{~b}$ & $2.12 \mathrm{c}$ & nd d \\
\hline \multicolumn{13}{|c|}{ Furanoic compounds } \\
\hline $\begin{array}{l}\text { 2-Pentyl-furan } \\
\text { Dihydro-2-methyl-3(2H)- } \\
\text { furanone }\end{array}$ & $\begin{array}{l}1221 \\
1264\end{array}$ & $\begin{array}{c}\text { Floral, fruity, green, earthy } \\
\text { Woody, bready }\end{array}$ & $\begin{array}{l}\mathrm{F}, \mathrm{LO}, \mathrm{MR} \\
\mathrm{MR}, \mathrm{CR}\end{array}$ & $\begin{array}{l}56.00 \mathrm{~b} \\
4.96 \mathrm{c}\end{array}$ & $\begin{array}{c}56.99 \mathrm{~b} \\
6.38 \mathrm{c}\end{array}$ & $\begin{array}{l}22.30 \mathrm{c} \\
6.74 \mathrm{c}\end{array}$ & $\begin{array}{l}62.93 \mathrm{~b} \\
13.50 \mathrm{~b}\end{array}$ & $\begin{array}{l}56.49 \mathrm{~b} \\
20.61 \mathrm{a}\end{array}$ & $\begin{array}{l}36.67 \mathrm{c} \\
21.67 \mathrm{a}\end{array}$ & $\begin{array}{l}94.65 \mathrm{a} \\
13.50 \mathrm{~b}\end{array}$ & $\begin{array}{l}61.94 \mathrm{~b} \\
18.83 \mathrm{a}\end{array}$ & $\begin{array}{l}27.75 \mathrm{c} \\
25.23 \mathrm{a}\end{array}$ \\
\hline $\begin{array}{c}\text { Furfural } \\
\text { Acetyl furan } \\
\text { 5-Methyl-Furfural }\end{array}$ & $\begin{array}{l}1468 \\
1509 \\
1584\end{array}$ & $\begin{array}{c}\text { Spicy, bready } \\
\text { Bready, caramel } \\
\text { Sweet, caramellic, bready }\end{array}$ & $\begin{array}{l}\text { MR, R } \\
\text { MR } \\
\text { MR }\end{array}$ & $\begin{array}{c}159.56 c \\
0.53 c \\
10.04 d\end{array}$ & $\begin{array}{l}167.59 \mathrm{c} \\
26.47 \mathrm{~b} \\
23.58 \mathrm{c}\end{array}$ & $\begin{array}{c}588.56 a \\
43.94 a \\
47.17 a\end{array}$ & $\begin{array}{c}291.02 \mathrm{~b} \\
5.29 \mathrm{c} \\
9.53 \mathrm{~d}\end{array}$ & $\begin{array}{l}639.24 a \\
35.47 a \\
36.63 b\end{array}$ & $\begin{array}{l}651.28 \mathrm{a} \\
48.70 \mathrm{a} \\
31.11 \mathrm{~b}\end{array}$ & $\begin{array}{c}279.48 \mathrm{~b} \\
7.94 \mathrm{c} \\
6.52 \mathrm{~d}\end{array}$ & $\begin{array}{l}616.66 a \\
21.18 b \\
37.63 b\end{array}$ & $\begin{array}{l}730.06 a \\
33.35 a \\
55.69 a\end{array}$ \\
\hline $\begin{array}{c}\text { Dihydro-2(3H)-Furanone } \\
\quad(\gamma \text {-Butyrolactone })\end{array}$ & 1648 & Burnt, sweet cream & $\mathrm{F}, \mathrm{MR}$ & $11.01 \mathrm{c}$ & $18.47 \mathrm{~b}$ & $23.45 b$ & $29.85 b$ & $42.66 a$ & $47.28 \mathrm{a}$ & $37.68 \mathrm{a}$ & $40.88 \mathrm{a}$ & $44.08 \mathrm{a}$ \\
\hline $\begin{array}{c}\text { Furfuryl alcohol } \\
\text { Total }\end{array}$ & 1666 & Biscuit, cake crust, caramelised & LO, MR, CR & $\begin{array}{l}17.41 d \\
259.51\end{array}$ & $\begin{array}{c}102.85 b \\
\mathbf{4 0 2 . 3 3}\end{array}$ & $\begin{array}{c}120.78 b \\
852.94\end{array}$ & $\begin{array}{l}74.37 \mathrm{c} \\
486.49\end{array}$ & $\begin{array}{c}152.95 b \\
\mathbf{9 8 4 . 0 5}\end{array}$ & $\begin{array}{l}310.13 a \\
\mathbf{1 1 4 6 . 8 4}\end{array}$ & $\begin{array}{l}31.12 d \\
470.89\end{array}$ & $\begin{array}{l}53.80 \mathrm{c} \\
850.92\end{array}$ & $\begin{array}{c}87.55 b \\
1003.71\end{array}$ \\
\hline
\end{tabular}

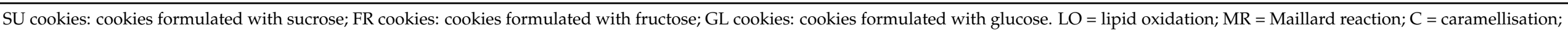

$\mathrm{F}=$ fermentation; different letters in the same row indicate a statistically significant differences $(p<0.05)$. 
To obtain further information, a difference in means investigation using ANOVA and Tukey's test was applied to the volatile compounds data (Table 3) and distinct trends were observed among the samples.

As regards esters, ethyl-butanoate and ethyl-octanoate are usually associated with fruity notes and arise from lipid peroxidation (LO) and further esterification with ethanol by yeast and bacteria or enzymes that are already present among the ingredients [57]. In agreement with the above-reported data, the amounts of these compounds were not influenced by the sugar type used in the formulation and decreased as the temperature increased.

Among the ketones, linear ketones, such as 2-pentanone, 2-heptanone, and 2-nonanone (sweet and fruity notes), arose from the LO [58,59]. Their concentrations were the highest in the GL and FR cookies, particularly when the $150{ }^{\circ} \mathrm{C}-20 \mathrm{~min}$ and $170{ }^{\circ} \mathrm{C}-20 \mathrm{~min}$ baking conditions were used. Their lower amounts at the highest temperature and shortest time (190 ${ }^{\circ} \mathrm{C}-15 \mathrm{~min}$ ) could have been due to the increased content of the MR products, which, in addition to giving the characteristic bakery product aroma, were demonstrated to have antioxidant activity by protecting lipids from oxidation [59-61]. Diacetyl, arising from the MR, was also observed; it is responsible for buttery, sweety, and creamy notes and showed a content that was slightly higher in the GL and FR samples in the $170{ }^{\circ} \mathrm{C}-20 \mathrm{~min}$ and $190^{\circ} \mathrm{C}-15$ min baking conditions. Moreover, acetoin (sweet, buttery, creamy, dairy) showed the highest content in the FR and GL cookies, its content decreased as the cooking time and temperature decreased and increased, respectively. Acetoin was found in free gluten bread, and it could be enzymatically formed from pyruvate and could be converted into diacetyl non-enzymatically; it could also arise from the MR [57]. 4-Cyclopentene-1,3-dione, another MR product, showed statistically significant differences in FR and GL samples in the $190{ }^{\circ} \mathrm{C}-15$ min baking condition; it was previously identified in model samples that were prepared with GL and hydrolyzed proteins subjected to the MR [62].

Aldehydes, in particular hexanal (green, fatty, leafy, fruity) and benzaldehyde (sweet, almond, fruity), are typical volatile compounds in bakery products [63] and are precursors of aromatic compounds, such as alcohols and esters. Of interest, the resulting content of hexanal, an LO product, was higher in the GL cookies at $150{ }^{\circ} \mathrm{C}-20 \mathrm{~min}$ baking condition. The same behaviour was also observed for the other aliphatic aldehydes (LO products), which can be volatile aromatic compounds that are already present in flour [64], and also for benzaldehyde, which can be formed from the amino acid phenylalanine via Streker degradation or oxidation [65].

Diacetone alcohol, an AGEs' precursor that is produced during the MR, was the highest in cookies baked at $170{ }^{\circ} \mathrm{C}$ and $190^{\circ} \mathrm{C}$, particularly in the GL and FR ones. Huang et al. [66] showed that the formation of this compound is enhanced if alkaline conditions are present. $\beta$-Phenylethyl alcohol, an MR product that is responsible for a rose-honey-like odour and considered as a typical alcohol in bakery products, did not show any statistically significant difference among samples [67].

The acetic acid content was quite stable between the samples, even if a little increase in the FR cookies baked at $190^{\circ} \mathrm{C}$ was observed. Acetic acid could be formed via fermentation or via sugar degradation throughout the MR $[57,68]$.

Pyrazines are important aromatic compounds in bakery products, and they are compounds that arise from both MR and LO [69]. 2-methylpyrazine (roasted, burnt, sweet) did not show significant differences between samples.

Furanic compounds were, quantitatively, the main class of compounds identified in the cookie samples. They mainly arise from the MR but can also be produced during fermentation or from LO. In our samples, most of the furanic compounds showed statistically significant differences between samples. The content of 2-pentyl furan was higher in all formulations in the $150{ }^{\circ} \mathrm{C}-25 \mathrm{~min}$ and $170{ }^{\circ} \mathrm{C}-20 \mathrm{~min}$ baking conditions and lower in the samples baked at $190{ }^{\circ} \mathrm{C}-15 \mathrm{~min}$. The content of dihydro-2-methyl-3(2 H)-furanone, also known as coffee furanone (woody, bready), was higher in the GL and FR cookies at $170{ }^{\circ} \mathrm{C}-20 \mathrm{~min}$ and $190{ }^{\circ} \mathrm{C}-15 \mathrm{~min}$. It was also identified in brown sugar sponge cake 
as an MR product [59,70]. Furfural is formed from sugar dehydration during an MR. In the cookie samples, its content was the highest in all formulations in the $190^{\circ} \mathrm{C}-15 \mathrm{~min}$ cooking conditions, but it also notably increased in the FR and GL cookies at $170^{\circ} \mathrm{C}-20 \mathrm{~min}$. It was identified in sponge cake cooked at $139^{\circ} \mathrm{C}$ for $35 \mathrm{~min}$ and its content could increase if a protein source, such as leucine, was added [71]. Our results are in agreement with Srivastava et al. [71], who affirmed that the content of furfural in baked goods is higher if reducing sugars are present. Acetyl furan (bready, caramel) and 5-methyl furfural (sweet, caramel, bready) levels were found to be higher in all formulations in the $190{ }^{\circ} \mathrm{C}-15 \mathrm{~min}$ baking condition. 2(3H)-Furanone or $\gamma$-Butyrolactone (burnt, sweet, creamy) is a characteristic aromatic compound that is found in bakery products. Its content, as for 2-pentyl furan, was higher in the GL and FR samples at $170{ }^{\circ} \mathrm{C}-20$ min and $190^{\circ} \mathrm{C}-15$ min baking conditions. Furfuryl alcohol, the product of furfural reduction, increased as the cooking temperature increased in GL cookies without showing differences in the SU and FR ones.

To better understand the influence of the sugar formulations and baking conditions on the volatile aromatic compounds, principal component analysis (PCA) was applied to all the compounds reported in Table 3 (Figure 1).

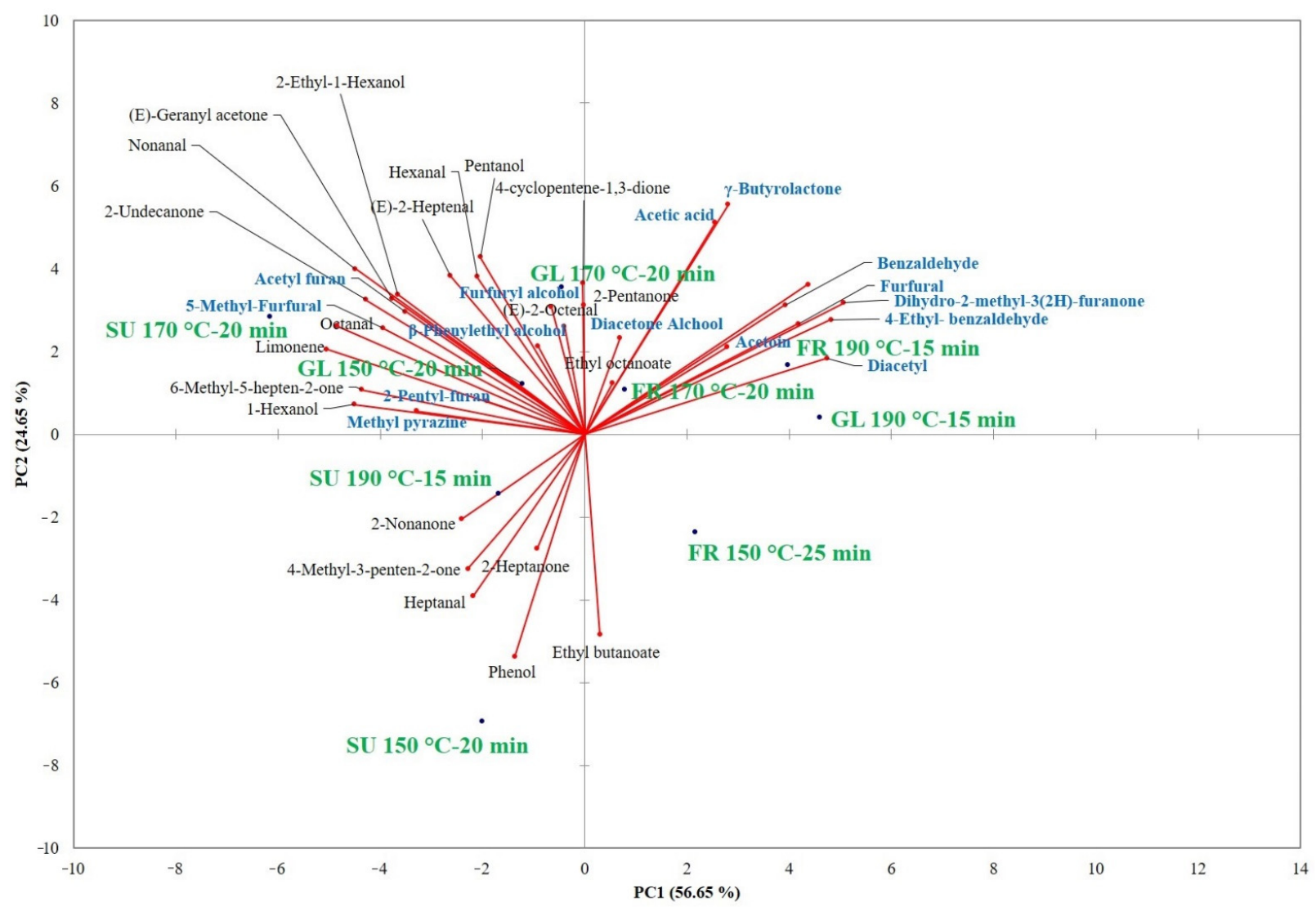

Figure 1. Principal component analysis (PCA) plot showing the multivariate variation between the SU, FR, and GL samples in terms of volatile aromatic compounds.

The first two components together explained $81.28 \%$ of the total variance (PC1 56.64\% and PC2 24.65\%). PCA allowed for separating all the SU and the $150{ }^{\circ} \mathrm{C}-20$ min GL cookies from the other samples since they were found on the negative side of PC1. These samples were found to be separated along the PC2 with the $190^{\circ} \mathrm{C}-15 \mathrm{~min}$ and $150^{\circ} \mathrm{C}-25 \mathrm{~min}$ SU samples on the negative side of PC2 and the $170{ }^{\circ} \mathrm{C}-20 \mathrm{~min} \mathrm{SU}$ and $150{ }^{\circ} \mathrm{C}-20 \mathrm{~min}$ GL samples on the positive side of PC2. The $170{ }^{\circ} \mathrm{C}-20 \mathrm{~min}$ and $190{ }^{\circ} \mathrm{C}-15 \mathrm{~min}$ GL and FR cookies were well separated on the positive sides of PC1 and PC2, while the $150{ }^{\circ} \mathrm{C}-25 \mathrm{~min}$ FR samples were on the positive side of PC1 and negative side of PC2. The variables that were mainly correlated on the negative sides of PC1 and PC2 were 2-ketones, esters, 
and aldehydes; hence, LO products mainly characterised the SU cookies at 150 and $190{ }^{\circ} \mathrm{C}$. Volatile compounds that are associated with $\mathrm{LO}$ (aldehydes, ketones, $\mathrm{C}_{13}$-norisoprenoids) and the MR (acetyl furan, furfuryl alcohol, $\beta$-phenylethyl alcohol, 5-methyl-furfural) were the variables that were mainly correlated on the positive PC2 and negative PC1 side, highlighting that reducing sugars were prone to undergo MRs faster than disaccharides.

The GL and FR cookies at $170{ }^{\circ} \mathrm{C}-20 \mathrm{~min}$ and $190^{\circ} \mathrm{C}-15 \mathrm{~min}$ were located on the positive sides of $\mathrm{PC} 1$ and $\mathrm{PC} 2$, respectively. In this case, the variables that mainly influenced the separation were almost exclusively MR products (acetic acid, diacetyl, acetoin, benzaldehyde, 4-Ethyl-benzaldehyde, dihydro-2-methyl-3(2H)-furanone, Furfural, $\gamma$-Butyrolactone), demonstrating how this reaction took place more easily when reducing sugars were present and at a baking temperature of $170{ }^{\circ} \mathrm{C}$ or more.

Figure 2 shows a heat map that gives a graphical view of the volatile compounds data. The heatmap colours of the matrix indicate the strength of the correlation between the samples and aromatic compounds. Dark blue indicates a negative correlation $(-1)$, red indicates a positive correlation $(+1)$, and the shade indicates an in-between correlation. As shown in Figure 2, two different clusters of samples formed: one containing SU samples and the other containing FR and GL samples. This second cluster was further divided into a cluster correlating GL samples at $150{ }^{\circ} \mathrm{C}-25 \mathrm{~min}$ and $170{ }^{\circ} \mathrm{C}-20 \mathrm{~min}$ and two subclusters, one containing GL and FR samples at $190^{\circ} \mathrm{C}-15 \mathrm{~min}$ and other FR samples at $150{ }^{\circ} \mathrm{C}-25 \mathrm{~min}$ and $170{ }^{\circ} \mathrm{C}-20 \mathrm{~min}$. These findings agree with the results produced using PCA.

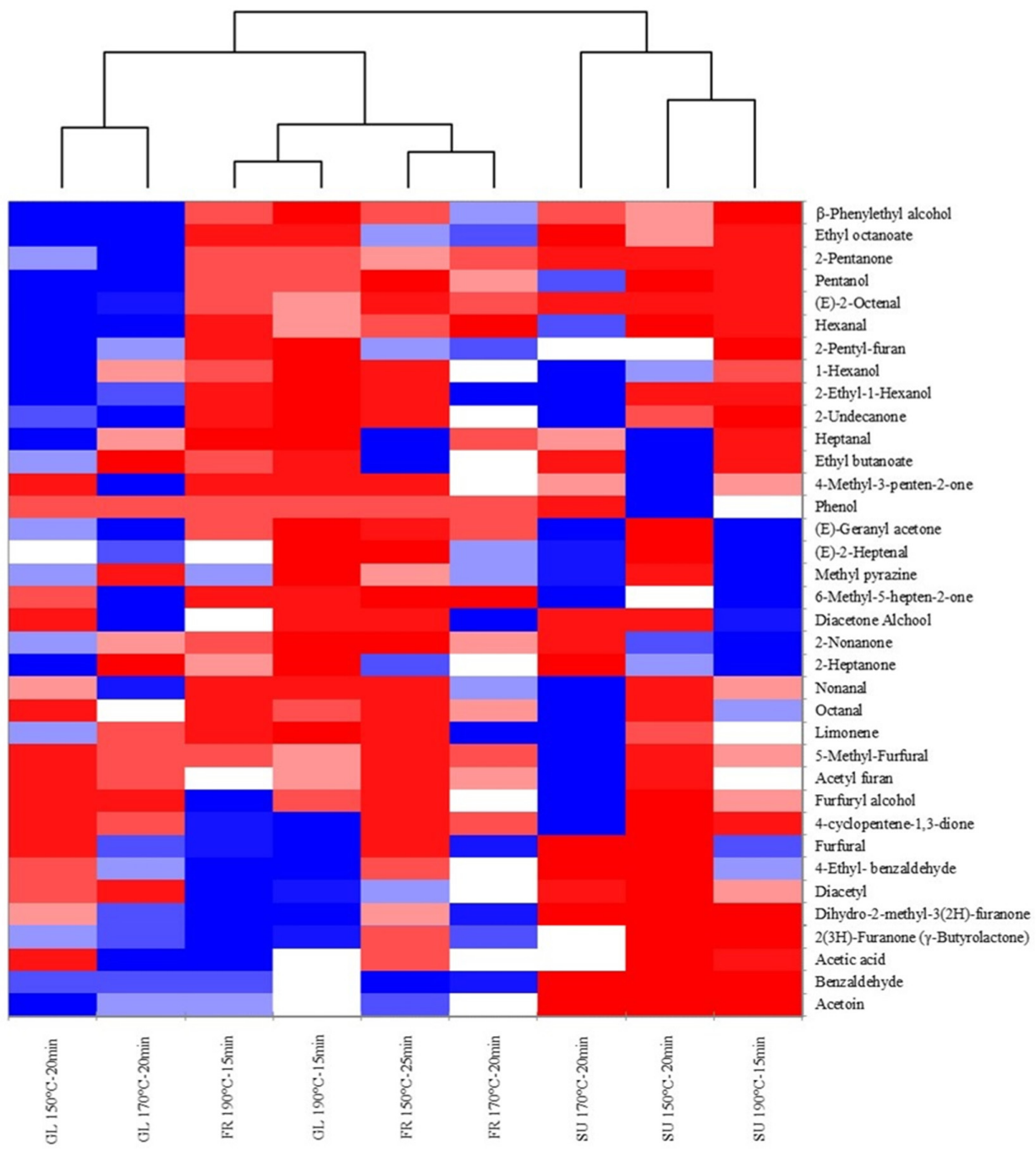

Figure 2. Heat map of the SU, FR, and GL samples using volatile aromatic compounds. 


\section{Conclusions}

In recent years, particular attention was focused on the chemical hazards formed in foods, particularly during thermal processing, and how to limit its accumulation. Cookies are one of the main commonly consumed ultra-processed foods, whose consumption was linked to the development of chronic diseases. This adverse effect is due to the poor nutritional quality of the food items and, lately, it was also hypothesised that a role is played by substances that are created during food processing.

The use of glucose and fructose syrup in cookie recipes is a widely used practice to improve the shelf life and cookies' texture. The results of the present study showed that the replacement of sucrose in the cookies' recipe with monosaccharides, such as fructose and glucose, had as a consequence the highest accumulation of $\alpha$-dicarbonyl compounds (mainly 3-DG and MGO), HMF, and furanoic volatile compounds in cookies at the OBT. Moreover, the ability to retain water, the titratable acidity, the $\mathrm{pH}$, and the main characteristic volatile aromatic compounds of the cookies were influenced. The use of both monosaccharides and the highest temperature produced volatile aromatic compounds that were almost exclusively characterised by MR products, indicating a faster development of this reaction during baking at the studied temperatures.

Author Contributions: Conceptualisation, E.A., A.V. and B.F.; methodology, E.A. and A.V.; validation, F.C., C.C. and S.B.; formal analysis, S.B., C.C. and F.C.; investigation, F.C., C.C. and S.B.; writing-original draft preparation, E.A., A.V. and B.F.; writing-review and editing, E.A.; funding acquisition, E.A. All authors read and agreed to the published version of the manuscript.

Funding: This research was supported by the Project "SicurNaturBio-Sicurezza e attività funzionale su sistemi biologici di estratti naturali da impiegare in formulazioni alimentari," which was funded by the Programma ricerca di ateneo UNICT 2020-22 linea 2 of the University of Catania (Italy).

Institutional Review Board Statement: Ethical review and approval were waived for this study, as our institution does not have an ethics committee for taste and food quality evaluation studies.

Informed Consent Statement: Informed consent was obtained from all subjects involved in the study. Data Availability Statement: Not applicable.

Conflicts of Interest: The authors declare no conflict of interest. The funders had no role in the design of the study; in the collection, analyses, or interpretation of data; in the writing of the manuscript; or in the decision to publish the results.

\section{References}

1. Amaya-Farfan, J.; Rodriguez-Amaya, D.B. Chapter 6-The Maillard reactions. In Chemical Changes During Processing and Storage of Foods; Rodriguez-Amaya, D.B., Amaya-Farfan, J., Eds.; Academic Press: London, UK, 2021. [CrossRef]

2. Wang, S.; Xu, H.; Luan, H.; Cai, J. Brief introduction of food processing methods and chemical hazards formed during thermal processing. In Chemical Hazards in Thermally-Processed Foods; Wang, S., Ed.; Springer Nature Singapore Pte. Ltd.: Singapore, 2019; pp. 1-17. [CrossRef]

3. Fujioka, K.; Shibamoto, T. Formation of genotoxic dicarbonyl compounds in dietary oils upon oxidation. Lipids 2004, 39, 481-486. [CrossRef]

4. Marceau, E.; Yaylayan, V.A. Profiling of $\alpha$-dicarbonyl content of commercial honeys from different botanical origins: Identification of 3,4-dideoxyglucoson-3-ene (3,4-DGE) and related compounds. J. Agric. Food Chem. 2009, 57, 10837-10844. [CrossRef] [PubMed]

5. Arena, E.; Ballistreri, G.; Fallico, B. Kinetics of 3-Deoxy-D-Erythro-Hexos-2-Ulose in Unifloral Honeys. J. Food Sci. 2011, 76, C1044-C1049. [CrossRef]

6. Arena, E.; Ballistreri, G.; Tomaselli, F.; Fallico, B. Survey of 1,2-Dicarbonyl Compounds in Commercial Honey of Different Floral Origin. J. Food Sci. 2011, 76, C1203-C1210. [CrossRef]

7. Degen, J.; Hellwig, M.; Henle, T. 1,2-Dicarbonyl Compounds in Commonly Consumed Foods. J. Agric. Food Chem. 2012, 60, 7071-7079. [CrossRef]

8. Hellwig, M.; Gensberger-Reigl, S.; Henle, T.; Pischetsrieder, M. Food-derived 1,2-dicarbonyl compounds and their role in diseases. Semin. Cancer Biol. 2018, 49, 1-8. [CrossRef]

9. Arribas-Lorenzo, G.; Morales, F.J. Analysis, Distribution, and Dietary Exposure of Glyoxal and Methylglyoxal in Cookies and Their Relationship with Other Heat-Induced Contaminants. J. Agric. Food Chem. 2010, 58, 2966-2972. [CrossRef] 
10. Maasen, K.; Scheijen, J.L.; Opperhuizen, A.; Stehouwer, C.D.; Van Greevenbroek, M.M.; Schalkwijk, C.G. Quantification of dicarbonyl compounds in commonly consumed foods and drinks; presentation of a food composition database for dicarbonyls. Food Chem. 2021, 339, 128063. [CrossRef] [PubMed]

11. Wang, Y.; Ho, C.-T. Flavour chemistry of methylglyoxal and glyoxal. Chem. Soc. Rev. 2012, 41, 4140-4149. [CrossRef]

12. Mavric, E.; Wittmann, S.; Barth, G.; Henle, T. Identification and quantification of methylglyoxal as the dominant antibacterial constituent of Manuka (Leptospermum scoparium) honeys from New Zealand. Mol. Nutr. Food Res. 2008, 52, 483-489. [CrossRef] [PubMed]

13. Hayashi, K.; Efukushima, A.; Ehasyashi-Nishino, M.; Enishino, K. Effect of methylglyoxal on multidrug-resistant Pseudomonas aeruginosa. Front. Microbiol. 2014, 5, 180. [CrossRef]

14. Brighina, S.; Restuccia, C.; Arena, E.; Palmeri, R.; Fallico, B. Antibacterial activity of 1,2-dicarbonyl compounds and the influence of the in vitro assay system. Food Chem. 2020, 311, 125905. [CrossRef]

15. Wang, J.; Chang, T. Methylglyoxal Content in Drinking Coffee as a Cytotoxic Factor. J. Food Sci. 2010, 75, H167-H171. [CrossRef]

16. Amoroso, A.; Maga, G.; Daglia, M. Cytotoxicity of $\alpha$-dicarbonyl compounds submitted to in vitro simulated digestion process. Food Chem. 2013, 140, 654-659. [CrossRef] [PubMed]

17. Brighina, S.; Turrado, C.P.; Restuccia, C.; Walton, G.; Fallico, B.; Oruna-Concha, M.J.; Arena, E. Detrimental effect on the gut microbiota of 1,2-dicarbonyl compounds after in vitro gastro-intestinal and fermentative digestion. Food Chem. 2021, $341,128237$. [CrossRef] [PubMed]

18. McCance, D.R.; Dyer, D.G.; Dunn, J.A.; Bailie, K.E.; Thorpe, S.R.; Baynes, J.W.; Lyons, T.J. Maillard reaction products and their relation to complications in insulin-dependent diabetes mellitus. J. Clin. Investig. 1993, 91, 2470-2478. [CrossRef]

19. Vitek, M.P.; Bhattacharya, K.; Glendening, J.M.; Stopa, E.; Vlassara, H.; Bucala, R.; Manogue, K.; Cerami, A. Advanced glycation end products contribute to amyloidosis in Alzheimer disease. Proc. Natl. Acad. Sci. USA 1994, 91, 4766-4770. [CrossRef]

20. Ahmed, N.; Thornalley, P. Advanced glycation endproducts: What is their relevance to diabetic complications? Diabetes Obes. Metab. 2007, 9, 233-245. [CrossRef] [PubMed]

21. Šebeková, K.; Somoza, V. Dietary advanced glycation endproducts (AGEs) and their health effects-PRO. Mol. Nutr. Food Res. 2007, 51, 1079-1084. [CrossRef] [PubMed]

22. Mogol, B.A.; Gökmen, V. Thermal process contaminants: Acrylamide, chloropropanols and furan. Curr. Opin. Food Sci. 2016, 7 , 86-92. [CrossRef]

23. Crews, C.; Castle, L. A review of the occurrence, formation and analysis of furan in heat-processed foods. Trends Food Sci. Technol. 2007, 18, 365-372. [CrossRef]

24. Condurso, C.; Cincotta, F.; Verzera, A. Determination of furan and furan derivatives in baby food. Food Chem. 2018, 250, 155-161. [CrossRef] [PubMed]

25. Knutsen, H.K.; Alexander, J.; Barregård, L.; Bignami, M.; Brüschweiler, B.; Ceccatelli, S.; Cottrill, B.; Dinovi, M.; Edler, L.; Grasl-Kraupp, B.; et al. Risks for public health related to the presence of furan and methylfurans in food. EFSA J. 2017, 15, e05005. [CrossRef] [PubMed]

26. Okaru, A.O.; Lachenmeier, D.W. The Food and Beverage Occurrence of Furfuryl Alcohol and Myrcene-Two Emerging Potential Human Carcinogens? Toxics 2017, 5, 9. [CrossRef]

27. IARC International Agency for Research on Cancer. Furan. In IARC Monographs; World Health Organization: Lyon, France, 1995; Volume 63, pp. 393-407.

28. EFSA Panel on Food Contact Materials, Enzymes, Flavourings and Processing Aids. Scientific opinion on flavouring group evaluation 67, revision 1 (FGE.67Rev.1): Consideration of 40 furan-substituted aliphatic hydrocarbons, alcohols, aldehydes, ketones, carboxylic acids and related esters, sulfides, disulfides and ethers evaluated by JECFA at the 65th meeting (JECFA, 2006b) and re-evaluated at the 69th meeting (JECFA, 2009c). EFSA J. 2011, 9, 2315.

29. Kim, J.-S.; Her, J.-Y.; Lee, K.-G. Formation and reduction of carcinogenic furan in various model systems containing food additives. Food Chem. 2015, 189, 108-113. [CrossRef]

30. Belitz, H.B.; Grosch, W.; Schieberle, P. Food Chemistry, 3rd ed.; Springer: Berlin, Germany, 2004; pp. $258-282$.

31. Ramírez-Jiménez, A.; García-Villanova, B.; Guerra-Hernández, E. Hydroxymethylfurfural and methylfurfural content of selected bakery products. Food Res. Int. 2000, 33, 833-838. [CrossRef]

32. Rada-Mendoza, M.; Olano, A.; Villamiel, M. Determination of hydroxymethylfurfural in commercial jams and in fruit-based infant foods. Food Chem. 2002, 79, 513-516. [CrossRef]

33. Fallico, B.; Zappalà, M.; Arena, E.; Verzera, A. Effects of conditioning on HMF content in unifloral honeys. Food Chem. 2004, 85, 305-313. [CrossRef]

34. Capuano, E.; Fogliano, V. Acrylamide and 5-hydroxymethylfurfural (HMF): A review on metabolism, toxicity, occurrence in food and mitigation strategies. LWT Food Sci. Technol. 2011, 44, 793-810. [CrossRef]

35. Spina, A.; Brighina, S.; Muccilli, S.; Mazzaglia, A.; Rapisarda, P.; Fallico, B.; Arena, E. Partial Replacement of NaCl in Bread from Durum Wheat (Triticum turgidum L subsp. durum Desf.) with $\mathrm{KCl}$ and Yeast Extract: Evaluation of Quality Parameters During Long Storage. Food Bioprocess Technol. 2015, 8, 1089-1101. [CrossRef]

36. Spina, A.; Brighina, S.; Muccilli, S.; Mazzaglia, A.; Fabroni, S.; Fallico, B.; Rapisarda, P.; Arena, E. Wholegrain Durum Wheat Bread Fortified with Citrus Fibers: Evaluation of Quality Parameters During Long Storage. Front. Nutr. 2019, 6, 13. [CrossRef] 
37. Arena, E.; Muccilli, S.; Mazzaglia, A.; Giannone, V.; Brighina, S.; Rapisarda, P.; Fallico, B.; Allegra, M.; Spina, A. Development of Durum Wheat Breads Low in Sodium Using a Natural Low-Sodium Sea Salt. Foods 2020, 9, 752. [CrossRef]

38. Ramírez-Jiménez, A.; Guerra-Hernández, E.; García-Villanova, B. Browning Indicators in Bread. J. Agric. Food Chem. 2000, 48, 4176-4181. [CrossRef]

39. Petisca, C.; Henriques, A.; Pérez-Palacios, T.; Pinho, O.; Ferreira, I. Assessment of hydroxymethylfurfural and furfural in commercial bakery products. J. Food Compos. Anal. 2014, 33, 20-25. [CrossRef]

40. Abraham, K.; Gürtler, R.; Berg, K.; Heinemeyer, G.; Lampen, A.; Appel, K.E. Toxicology and risk assessment of 5Hydroxymethylfurfural in food. Mol. Nutr. Food Res. 2011, 55, 667-678. [CrossRef] [PubMed]

41. Monien, B.H.; Engst, W.; Barknowitz, G.; Seidel, A.; Glatt, H. Mutagenicity of 5-Hydroxymethylfurfural in V79 Cells Expressing Human SULT1A1: Identification and Mass Spectrometric Quantification of DNA Adducts Formed. Chem. Res. Toxicol. 2012, 25, 1484-1492. [CrossRef] [PubMed]

42. Fan, X.; Mastovska, K. Effectiveness of Ionizing Radiation in Reducing Furan and Acrylamide Levels in Foods. J. Agric. Food Chem. 2006, 54, 8266-8270. [CrossRef] [PubMed]

43. Anese, M.; Bot, F.; Suman, M. Furan and 5-hydroxymethylfurfural removal from high- and low-moisture foods. LWT Food Sci. Technol. 2014, 56, 529-532. [CrossRef]

44. Manley, D.J.R. Biscuit, Cracker, and Cookie Recipes for the Food Industry, 1st ed.; Duncan, J.R., Ed.; CRC Press: Boca Raton, FL, USA, 2001; p. 208.

45. Lefebvre, D.; Gabriel, V.; Vayssier, Y.; Fontagné-Faucher, C. Simultaneous HPLC Determination of Sugars, Organic Acids and Ethanol in Sourdough Process. LWT Food Sci. Technol. 2002, 35, 407-414. [CrossRef]

46. Weigel, K.U.; Opitz, T.; Henle, T. Studies on the occurrence and formation of 1,2-dicarbonyls in honey. Eur. Food Res. Technol. 2004, 218, 147-151. [CrossRef]

47. Cincotta, F.; Tripodi, G.; Merlino, M.; Verzera, A.; Condurso, C. Variety and shelf-life of coffee packaged in capsules. LWT 2020, 118, 108718. [CrossRef]

48. Ureta, M.; Olivera, D.F.; Salvadori, V.O. Quality Attributes of Muffins: Effect of Baking Operative Conditions. Food Bioprocess Technol. 2014, 7, 463-470. [CrossRef]

49. Ureta, M.M.; Olivera, D.F.; Salvadori, V.O. Baking of muffins: Kinetics of crust color development and optimal baking time. Food Bioprocess Technol. 2014, 7, 3208-3216. [CrossRef]

50. Ameur, L.; Mathieu, O.; Lalanne, V.; Trystram, G.; Birlouezaragon, I. Comparison of the effects of sucrose and hexose on furfural formation and browning in cookies baked at different temperatures. Food Chem. 2007, 101, 1407-1416. [CrossRef]

51. Ameur, L.A.; Trystram, G.; Birlouez-Aragon, I. Accumulation of 5-hydroxymethyl-2-furfural in cookies during the backing process: Validation of an extraction method. Food Chem. 2006, 98, 790-796. [CrossRef]

52. Kowalski, S.; Lukasiewicz, M.; Juszczak, L.; Kutyła-Kupidura, E.M. Dynamics of 5-hydroxymethylfurfural formation in shortbreads during thermal processing. Czech J. Food Sci. 2013, 31, 33-42. [CrossRef]

53. Gökmen, V.; Açar, O.; Köksel, H.; Acar, J. Effects of dough formula and baking conditions on acrylamide and hydroxymethylfurfural formation in cookies. Food Chem. 2007, 104, 1136-1142. [CrossRef]

54. Courel, M.; Ait-Ameur, L.; Capuano, E.; Fogliano, V.; Morales, F.J.; Courtois, F.; Birlouez-Aragon, I. Effects of Formulation and Baking Conditions on Neo-formed Contaminants in Model Cookies. Czech J. Food Sci. 2009, 27, S93-S95. [CrossRef]

55. Wells-Knecht, K.J.; Zyzak, D.V.; Litchfield, J.E.; Thorpe, S.R.; Baynes, J.W. Mechanism of autoxidative glycosylation: Identification of Glyoxal and Arabinose as Intermediates in the Autoxidative Modification of Proteins by Glucose. Biochemistry 1995, 34, 3702-3709. [CrossRef]

56. Weenen, H. Reactive intermediates and carbohydrate fragmentation in Maillard chemistry. Food Chem. 1998, 62, 393-401. [CrossRef]

57. Pico, J.; Martínez, M.M.; Bernal, J.; Gomez, M. Evolution of volatile compounds in gluten-free bread: From dough to crumb. Food Chem. 2017, 227, 179-186. [CrossRef]

58. Garvey, E.C.; O'Sullivan, M.G.; Kerry, J.P.; Kilcawley, K.N. Optimisation of HS-SPME Parameters for the Analysis of Volatile Compounds in Baked Confectionery Products. Food Anal. Methods 2020, 13, 1314-1327. [CrossRef]

59. Garvey, E.; O'Sullivan, M.; Kerry, J.; Milner, L.; Gallagher, E.; Kilcawley, K.N. Characterising the sensory quality and volatile aroma profile of clean-label sucrose reduced sponge cakes. Food Chem. 2021, 342, 128124. [CrossRef]

60. Yu, M.; He, S.; Tang, M.; Zhang, Z.; Zhu, Y.; Sun, H. Antioxidant activity and sensory characteristics of Maillard reaction products derived from different peptide fractions of soybean meal hydrolysate. Food Chem. 2018, 243, 249-257. [CrossRef] [PubMed]

61. Tu, Y.; Xu, Y.; Ren, F.; Zhang, H. Characteristics and antioxidant activity of Maillard reaction products from $\alpha$-lactalbumin and 2'-fucosyllactose. Food Chem. 2020, 316, 126341. [CrossRef] [PubMed]

62. Su, G.; Zheng, L.; Cui, C.; Yang, B.; Ren, J.; Zhao, M. Characterization of antioxidant activity and volatile compounds of Maillard reaction products derived from different peptide fractions of peanut hydrolysate. Food Res. Int. 2011, 44, 3250-3258. [CrossRef]

63. Zhang, H.; Chen, H.; Wang, W.; Jiao, W.; Chen, W.; Zhong, Q.; Yun, Y.-H.; Chen, W. Characterization of Volatile Profiles and Marker Substances by HS-SPME/GC-MS during the Concentration of Coconut Jam. Foods 2020, 9, 347. [CrossRef]

64. Maire, M.; Rega, B.; Cuvelier, M.-E.; Soto, P.; Giampaoli, P. Lipid oxidation in baked products: Impact of formula and process on the generation of volatile compounds. Food Chem. 2013, 141, 3510-3518. [CrossRef] [PubMed] 
65. Cheng, H.; Erichsen, H.; Soerensen, J.; Petersen, M.A.; Skibsted, L.H. Optimising water activity for storage of high lipid and high protein infant formula milk powder using multivariate analysis. Int. Dairy J. 2019, 93, 92-98. [CrossRef]

66. Huang, J.; Ren, J.; Tao, G.; Chen, Y.; Yao, S.; Han, D.; Qiu, R. Maize bran feruloylated oligosaccharides inhibited AGEs formation in glucose/amino acids and glucose/BSA models. Food Res. Int. 2019, 122, 443-449. [CrossRef] [PubMed]

67. Dueñas-Sánchez, R.; Pérez, A.G.; Codón, A.C.; Benítez, T.; Rincón, A.M. Overproduction of 2-phenylethanol by industrial yeasts to improve organoleptic properties of bakers' products. Int. J. Food Microbiol. 2014, 180, 7-12. [CrossRef]

68. Pico, J.; Bernal, J.; Gomez, M. Wheat bread aroma compounds in crumb and crust: A review. Food Res. Int. 2015, 75, 200-215. [CrossRef] [PubMed]

69. Pico, J.; Tapia, J.A.; Bernal, J.; Gomez, M. Comparison of different extraction methodologies for the analysis of volatile compounds in gluten-free flours and corn starch by GC/QTOF. Food Chem. 2018, 267, 303-312. [CrossRef]

70. Liu, J.; Wan, P.; Xie, C.; Chen, D.-W. Key aroma-active compounds in brown sugar and their influence on sweetness. Food Chem. 2021, 345, 128826. [CrossRef]

71. Srivastava, R.; Bousquières, J.; Cepeda-Vázquez, M.; Roux, S.; Bonazzi, C.; Rega, B. Kinetic study of furan and furfural generation during baking of cake models. Food Chem. 2018, 267, 329-336. [CrossRef] [PubMed] 